\title{
MAKNA KEBANGKITAN KRISTUS BERDASARKAN I KORINTUS 15:12-28 DAN IMPLIKASINYA BAGI ORANG PERCAYA
}

\author{
Nicolas Rande ${ }^{1}$ \\ sttjaffraymakassar@yahoo.co.id \\ Daniel Ronda \\ danielronda@ymail.com
}

\begin{abstract}
ABSTRAK
Sesuai dengan pokok masalah yang ada, maka yang menjadi tujuan dalam penulisan karya ilmiah ini adalah: Pertama, untuk menjelaskan makna kebangkitan Kristus berdasarkan I Korintus 15:12-28. Kedua, untuk menjelaskan implikasi dari makna kebangkitan Kristus bagi orang percaya.

Adapun metode penulisan yang digunakan adalah: menggunakan hermeneutika metode eksegesis Alkitab, yang sumbernya berkaitan langsung dari literatur (Library Research) dengan menggunakan buku-buku pendukung yang relevan dengan judul yang dibahas oleh penulis dan disertai bantuan media elektronik.

Adapun kesimpulan karya ilmiah "Makna Kebangkitan Kristus Berdasarkan I Korintus 15:12-28 Dan Implikasinya Bagi Orang Percaya" adalah Pertama, Kristus adalah Allah yang menjadi manusia sejati. Sebagai manusia Kristus mengalami kematian tubuh. Tetapi di dalam Dia, Allah hadir dan bertindak membangkitkanNya dari kematian itu. Kedua, kebangkitan Kristus adalah bagian dari Injil yang utuh yang diberitakan sekaligus meneguhkan pemberitaan Injil. Sebab, pemberitaan Injil yang lengkap tidak terpisahkan dari peristiwa dan pemberitaan kebangkitan Kristus. Ketiga, kebangkitan Kristus menjadi penentu dari seluruh ajaran Kristen sehingga tegak atau runtuhnya iman Kristen didasarkan kepada realitas kebangkitan Kristus. Keempat, kebangkitan Kristus adalah salah satu penentu tentang jaminan karya penebusan Allah yang sempurna melalui Anak-Nya yaitu Yesus Kristus. Kelima, kebangkitan Kristus adalah dasar kebangkitan orang-orang percaya pada saat kedatangan Kristus yang kedua kalinya (parousia).
\end{abstract}

Kata Kunci: Kebangkitan Kristus, I Korintus 15:12-28

\footnotetext{
${ }^{1}$ Nicolas Rande adalah alumni S1 STT Jaffray Makassar 2012.
} 


\section{PENDAHULUAN}

\section{Latar Belakang Masalah}

Salah satu peristiwa sejarah yang sangat besar pengaruhnya sampai saat ini adalah tentang peristiwa kebangkitan Tuhan Yesus Kristus. Kebangkitan Kristus, memiliki pengaruh yang begitu luas baik itu di kalangan umat Kristiani maupun di kalangan orang-orang yang menolak kebangkitan. Umat Kristiani mengimani bahwa Kristus telah dibangkitkan. Kebangkitan Kristus membuktikan kemenangan-Nya terhadap kuasa maut, dosa, dan iblis. Sehingga menjadi suatu keyakinan yang pasti bahwa, Kristus adalah Allah yang hidup dan berkuasa atas segalanya.

Di kalangan orang-orang percaya, kebangkitan Tuhan Yesus merupakan fondasi iman Kristen. Paulus dalam suratnya kepada jemaat Korintus, mengatakan, "Kalau tidak ada kebangkitan orang mati, maka Kristus juga tidak dibangkitkan. Tetapi andaikata Kristus tidak dibangkitkan, maka sia-sialah pemberitaan kami dan sia-sialah juga kepercayaan kamu" (I Korintus 15:13-14). Dalam ayat 16 dan 17, "Sebab jika benar orang mati tidak dibangkitkan, maka Kristus juga tidak dibangkitkan. Dan jika Kristus tidak dibangkitkan, maka sia-sialah kepercayaan kamu dan kamu hidup dalam dosamu" (I Korintus 15:1617). ${ }^{2}$ Sangat jelas bahwa melalui kebangkitan Kristus, orang Kristen memiliki iman dan pengharapan. Itu berarti bahwa kebangkitan Kristus memiliki makna bagi orang-orang percaya. Seperti yang dikatakan oleh Donald Guthrie, "Makna utama kebangkitan ialah kontribusi yang diberikannya bagi pengertian kita mengenai pribadi dan pekerjaan Kristus." ${ }^{3}$

Bahkan hari-hari ini, berita kebangkitan Kristus masih menjadi polemik. Ada beberapa pandangan yang menggugat serta meragukan tentang kebangkitan Tuhan Yesus yang ditinjau dari beberapa aspek sehingga menimbulkan kontroversi. Sehubungan dengan kontroversi tentang penemuan makam yang diduga adalah makam keluarga Yesus dan berisi tulang-tulang Yesus dan keluarganya, Ioanes Rakhmat pernah memberikan komentarnya di sebuah media cetak,

Jika sisa-sisa jasad Yesus memang ada di bumi ini, maka kebangkitan dan kenaikan Yesus ke surga tidak bisa lagi dipahami sebagai kejadian-kejadian sejarah objektif, melainkan sebagai metafora. Para penulis Perjanjian Baru sendiri pasti memahami keduanya sebagai metafora; jika tidak demikian, mereka adalah

\footnotetext{
${ }^{2}$ I Korintus 15: 13-14, 16-17 (TB).

${ }^{3}$ Donald Guthrie, Teologi Perjanjian Baru l (Jakarta:BPK Gunung Mulia, 1992), 445.
} 
orang-orang yang sudah tidak lagi memiliki kemampuan membedakan mana realitas dan mana fantasi dan delusi. Dalam metafora sebuah kejadian hanya ada di dalam pengalaman subjektif, bukan dalam realitas objektif. Yesus bangkit, ya, tetapi bangkit di dalam memori dan pengalaman hidup dihadiri dan dibimbing oleh Rohnya. Yesus telah naik ke surga, ya; dalam arti: ia telah diangkat dalam roh untuk berada di sisi Allah di kawasan rohani surgawi. ${ }^{4}$

Pandangan berikutnya yang menolak kebangkitan Kristus yaitu adanya anggapan bahwa kebangkitan Kristus hanyalah imajinasi para murid. Ajith Fernando menuliskan mengenai pendapat A. N. Wilson, "Dia menganggap, kepercayaan kepada adanya kebangkitan merupakan hasil imajinasi para murid." 5 Dan teori lainnya yang menolak kebangkitan Kristus, yaitu munculnya teori tentang kubur yang salah. C. Marvin Pate dan Sherly. L. Pate mengungkapkan,

Teori 'kubur yang salah' dipopulerkan oleh seorang ahli dari Harvard Kirsopp Lake, yang menulis buku The Historical Evidence for Resurrection of Jesus Christ. Dalam buku tersebut, dia berpendapat bahwa 'fakta-fakta di balik tradisi' kebangkitan Yesus adalah sebagai berikut: Karena ada banyak kubur yang berada di sekitar tempat Yesus dimakamkan, para wanita, yang bermaksud mengunjungi kubur Yesus pada hari Minggu pagi, bingung untuk menentukan kubur mana yang menjadi kubur Yesus. ${ }^{6}$

Kubur yang kosong dan yang ada hanyalah kain kafan saja, menandakan bahwa Ia sudah bangkit (Lukas 24:12). Adanya malaikat

\footnotetext{
4 "Buntut Tulisan Kontroversi Temuan Makam Keluarga Yesus"; diakses 07 Juni 2012; tersedia di http:/www.jawaban.com/index.php/mobile/news/detail_text_view/id/90/news/071018095337/page/167 0/limit/15 (Jika Anda membaca Kompas, 5 April 2007 lalu, Anda akan menemukan tulisan Pdt.Ioanes Rakhmat, Dosen Kajian Perjanjian Baru di Sekolah Tinggi Teologi (STT) Jakarta seperti yang dikutip oleh jawaban.com ini). Pada hari Kamis tanggal 5 April 2007 banyak orang Kristen dikejutkan dengan sebuah artikel di Harian Kompas yang ditulis oleh Pdt. Ioanes Rakhmat, dosen di Sekolah Tinggi Teologi(STT) Jakarta. Dalam artikel kontroversial tersebut Rakhmat mendukung pendapat yang mengatakan bahwa tulang-tulang Yesus dan anggota keluarga telah ditemukan di Talpiot, pinggiran Yerusalem. (Yakub Tri Handoko, "Kontroversi Seputar Penemuan Tulang-tulang di Talpiot"; diakses 27 Agustus 2012 tersedia di http://www.gkri-exodus.org/imageupload/APO\%2019\%20Kontroversi\%20Kuburan\%20Talpiot\%201.pdf)

${ }^{5}$ A. N. Wilson, Jesus: A life (New York: Ballatine, 1992), 66. Dikutip oleh Ajith Fernando, Supremasi Kristus (Surabaya; Penerbit Momentum, 2006), 243.

${ }^{6}$ C. Marvin Pate dan Sherly L. Pate, Disalibkan oleh Media (Yogyakarta: Penerbit ANDI, 2007), 202.
} 
yang mengatakan bahwa Tuhan Yesus telah bangkit kepada perempuanperempuan yang pergi ke kubur Tuhan Yesus (Lukas 24:5-7; Matius 28:5-7). Juga kesaksian yang disertai keberanian dan kuasa oleh rasulrasul, menguatkan tentang fakta kebangkitan Kristus. "Dengan kuasa yang besar, rasul-rasul memberi kesaksian tentang kebangkitan Tuhan Yesus ...." (Kisah Para Rasul 4:33). Begitupun ketika Paulus berada di Atena memberitakan Injil. "Dan juga beberapa ahli pikir dari golongan Epikuros dan Stoa bersoal jawab dengan dia ... Sebab ia memberitakan Injil tentang Yesus dan tentang kebangkitan-Nya" (Kisah Para Rasul 17:18). Kemudian Tuhan Yesus sendiri beberapa kali menampakkan diri kepada murid-murid-Nya sebelum Ia naik ke surga. Ia memperlihatkan tangan, kaki, dan juga lambung-Nya yang ditusuk (Yohanes 20:19-29; Lukas 24:13-49). Ia menampakkan diri kepada mereka secara nyata bukan imajinasi kepada para murid. Rasul Paulus juga mengatakan bahwa selain kedua belas murid-Nya dan semua rasul, Ia juga menampakkan diri kepada lebih dari lima ratus orang dan juga telah menampakkan diri kepada Paulus (I Korintus 15: 6 dan 8). Pada saat Tuhan Yesus menampakkan diri, hal tersebut menyatakan bahwa Ia telah bangkit. Ia memiliki otoritas atas kematian. Pusat dari fakta atas pemberitaan kebangkitan-Nya adalah ketika Kristus menampakkan diri. Jadi, semua bukti dan kesaksian tersebut mematahkan kebohongan dan pendapat yang menentang kebangkitan-Nya.

Berdasarkan latar belakang tersebut, hal inilah yang melatarbelakangi penulis untuk menulis suatu karya ilmiah yang berjudul, "Makna Kebangkitan Kristus Berdasarkan I Korintus 15:12-28 Dan Implikasinya Bagi Orang Percaya."

\section{Pokok Masalah}

Pertama, apakah makna kebangkitan Kristus di dalam I Korintus 15:12-28? Kedua, apakah implikasi makna kebangkitan Kristus bagi orang percaya?

\section{Tujuan Penulisan}

Pertama, untuk menjelaskan makna kebangkitan Kristus berdasarkan I Korintus 15:12-28. Kedua, untuk menjelaskan implikasi dari makna kebangkitan Kristus bagi orang percaya.

\section{Manfaat Penulisan}

Adapun manfaat dari penulisan karya ilmiah ini antara lain:

Pertama, sebagai dasar pemikiran bagi pembaca supaya memahami makna dari kebangkitan Kristus berdasarkan I Korintus 15:12-28 dan implikasinya bagi orang percaya. Kedua, menjadi pedoman bagi penulis di dalam pelayanan. 


\section{Metode Penelitian}

Dalam penulisan karya ilmiah ini, penulis menggunakan hermeneutika metode eksegesis Alkitab, yang sumbernya berkaitan langsung dari literatur (Library Research) dengan menggunakan bukubuku pendukung yang relevan dengan judul yang dibahas oleh penulis dan disertai bantuan media elektronik.

\section{Batasan Penulisan}

Sesuai dengan judul karya ilmiah ini, "Makna Kebangkitan Kristus Berdasarkan I Korintus 15:12-28 dan Implikasinya Bagi Orang Percaya". Oleh sebab itu, penulis khusus membahas tentang makna kebangkitan Kristus berdasarkan surat I Korintus 15:12-28. Penulis memilih judul ini sebab, melalui kebangkitan Kristus ada makna dari peristiwa tersebut. $\mathrm{Hal}$ itu tidak dapat dipisahkan dari karya keselamatan bagi umat manusia khususnya bagi orang percaya, sehingga kebangkitan Kristus menjadi dasar dari kekristenan, menjadi dasar kebangkitan orang-orang percaya, dan kebangkitan Kristus juga menyatakan kemenangan Allah terhadap semua musuh-Nya.

\section{EKSEGESIS I KORINTUS 15:12-28}

\section{Analisis Konteks}

Konteks Sebelum Teks (Ayat 1-11)

Dalam pasal 15:1-2 Paulus mengingatkan kepada jemaat Korintus tentang Injil yang telah diberitakannya dan diterima oleh jemaat serta di dalam Injil itu, jemaat teguh berdiri. Keselamatan itu diperoleh asal jemaat teguh berdiri di atas Injil itu. "Hasil pemberitaan Injil Kristus telah dinyatakan dalam ayat 1-2."7 Selanjutnya,"Dalam jemaat Korintus, ada beberapa orang yang telah menyangkal kebangkitan tubuh orang Kristen, karena itu Paulus hendak menasihati mereka. Mereka diselamatkan, "Asal kamu teguh berpegang padanya, seperti yang telah kuberitakan kepadamu."

Di dalam ayat 3-4, menyangkut isi tentang Injil yang diberitakan oleh Paulus. Injil itu meliputi pemberitaan tentang penyaliban, kematian, penguburan dan kebangkitan Kristus dan itu didasarkannya pada Kitab Suci. Paulus menekankan itu sebagai "yang sangat penting"(ayat 3).

Selanjutnya, dalam ayat 5-8 adalah fakta dari peristiwa kebangkitan itu. Setelah kebangkitan Kristus, Ia menampakkan diri

\footnotetext{
${ }^{7}$ J. Wesley Brill, Tafsiran Surat Pertama Korintus, 298.

${ }^{8}$ Ibid.
} 
kepada Kefas (ayat 5) dan kepada kedua belas murid-Nya (ayat 5). Sesudah itu, Ia menampakkan diri kepada lima ratus saudara sekaligus (ayat 6), kepada Yakobus, kemudian kepada semua rasul (ayat 7) yang paling akhir dari semuanya adalah Paulus. "Penekanan Paulus dalam ayat 6 adalah realitas historis dari kebangkitan. Jika seseorang tidak percaya, ada banyak saksi mata untuk bersaksi." 9 Ini merupakan fakta secara historis yang tidak dapat dibantah bahwa setelah kebangkitan Kristus, banyak yang menjadi saksi dari peristiwa tersebut.

Paulus menyatakan dalam ayat 8-11, bahwa Kristus menampakkan diri kepadanya sebagai yang paling akhir dari semuanya dan menganggap diriya sebagai yang paling hina dari semua rasul karena ia telah menganiaya jemaat Allah. Hanya oleh kasih karunia Allah, ia dipakai bersama dengan yang lainnya mengajar sehingga jemaat Korintus menjadi percaya. "Paulus mengagungkan kasih karunia Allah yang memungkinkannya untuk menjadi salah satu saksi dari kebangkitan Yesus" $(15: 8-11){ }^{10}$

\section{Konteks Sesudah Teks (Ayat 29-58)}

Dalam ayat 29, Paulus menghubungkan kebangkitan dengan perbuatan orang-orang yang dibaptis bagi orang mati. Kemudian, ayat 30-34 Paulus, menghubungkan kebangkitan orang mati dengan pengalaman hidup. Di mana mereka sering mengalami bahaya bersamasama dengan rekan-rekan pemberita Injil, khususnya Paulus. "Saudarasaudara, tiap-tiap hari aku berhadapan dengan maut" (ayat 31). Dikatakan pula bahwa Paulus telah melawan binatang buas di Efesus (ayat 32).

Namun dalam ayat 33-34 ia menegaskan, "Janganlah kamu sesat...." (dalam bentuk kata kerja adalah modus imperatif "perintah") kepada jemaat supaya mereka jangan disesatkan karena "Pergaulan yang buruk merusak kebiasaan yang baik". Dalam konteks jemaat Korintus, rupanya mereka masih terpengaruh praktik-praktik kafir dari masyarakat pada umumnya dan kebudayaan Yunani. Oleh sebab itu, Paulus menegur mereka atau memperingatkan mereka "sadarlah kembali..." (modus imperatif) dan "jangan berbuat dosa lagi" (modus imperatif). Di dalam ayat 35-58, Paulus menjawab pertanyaan tentang bagaimana cara orang mati

\footnotetext{
9"Surat-surat Paulus kepada Sebuah Gereja yang Bermasalah:I dan II Korintus" Bob Utley Guru Besar Hermeneutika (Penafsiran Alkitab) Kumpulan Komentari Panduan Belajar Perjanjian Baru, Vol. 8 Bible Lesson International, Marshall, Texas 1997 Revisi 2011;diakses tanggal 11-05-2012, tersedia dihttp://www.freebiblecommentary.org/pdf/ind/VOL06_indonesian.pdf

${ }^{10}$ Bob Utley "Surat-surat Paulus kepada Sebuah Gereja yang Bermasalah:I dan II Korintus" (Kumpulan Komentari Panduan Belajar, Perjanjian Baru, Vol. 8 Bible Lesson International, Marshall, Texas 1997 Revisi 2011).
} 
dibangkitkan dan dengan tubuh apakah mereka akan datang kembali (ayat 35). Jawaban Paulus di sini adalah yang ditaburkan tidak akan tumbuh atau hidup, kalau ia tidak mati dahulu (ayat 36). "Jawaban Paulus yang sederhana terhadap pertanyaan yang pertama ialah bahwa tubuh ini tidak akan hidup (dibangkitkan) kalau tidak mati dahulu. Kematian, yaitu musuh dari tubuh, sesungguhya merupakan sarana menuju kebangkitan." Untuk memberikan jawaban pada pertanyaan kedua, Paulus menganalogikan kebangkitan tubuh itu dengan beberapa benda (materi).

Pertama, tentang tumbuhan (biji) yang ditaburkan dan dihubungkan dengan ayat 36 bahwa yang ditaburkan tidak akan tumbuh atau hidup, kalau ia tidak mati dahulu. Dan yang ditaburkan bukanlah tubuh tanaman yang akan tumbuh, tetapi biji yang tidak berkulit umpamanya biji gandum atau biji lain (ayat 37). Dikatakannya bahwa Allah memberikan kepadanya suatu tubuh, seperti yang dikehendakinya. Allah memberikan kepada tiap-tiap biji tubuhnya sendiri (ayat 38).

Kedua, Paulus menganalogikan kebangkitan tubuh dengan beberapa jenis daging yang diperbandingkan. Bukan semua daging sama: Daging manusia lain daripada daging binatang, lain daripada daging burung, lain daripada daging ikan (ayat 39). Begitupun dengan tubuh. Ada tubuh sorgawi dan ada tubuh duniawi yang kemuliaannya berbeda (ayat 40). Menurut J. Wessley Brill, "Yang dimaksud Paulus dengan "tubuh duniawi" dalam ayat 40 ialah keempat macam daging yang disebutkan dalam ayat 39. Dan yang dimaksudkanya dengan 'tubuh sorgawi' ialah tubuh kebangkitan, dan tubuh itu berbeda sekali dengan tubuh duniawi." ${ }^{12}$

Ketiga, Paulus membandingkan tentang kemuliaan tubuh (tubuh rohani dan kemuliaan tubuh duniawi) dengan analogi kemuliaan matahari lain daripada kemuliaan bulan, dan kemuliaan bulan lain daripada kemuliaan bintang-bintang, dan kemuliaan bintang yang satu berbeda dengan kemuliaan bintang yang lain (ayat 41 ).

Dari ketiga analogi tersebut, di dalam ayat 42-44, Paulus menyebutkan ada empat hal yang berkaitan dengan kebangkitan orang mati. Pertama, ditaburkan dalam kebinasaan, dibangkitkan dalam ketidakbinasaan (ayat 42). "Tubuh kebangkitan tidak mungkin membusuk (bdg. ayat 53,54)." 13 Kedua, ditaburkan dalam kehinaan, dibangkitkan dalam kemuliaan (ayat 43). Ketiga, ditaburkan dalam kelemahan, dibangkitkan dalam kekuatan. "Tidak ada lagi prinsip dosa

\footnotetext{
${ }^{11}$ Ibid.

${ }^{12} \mathrm{~J}$. Wesley Brill, Tafsiran Surat Pertama Korintus, 318.

${ }^{13}$ Charles F. Pfeiffer dan Everett F. Harrison, Tafsiran Alkitab Wiycliffe Volume 3 Perjanjian Baru (Malang: Gandum Mas, 2001), 656.
} 
atau kelemahan fisik di dalamnya (ayat 43)." ${ }^{\text {14 }}$ Keempat, yang ditaburkan adalah tubuh alamiah, yang dibangkitkan adalah tubuh rohaniah (ayat 44a).

Selanjutnya dalam ayat 44b-49, Paulus mengatakan, jika ada tubuh alamiah, maka ada pula tubuh rohaniah. Dalam hal ini Paulus kembali membandingkan Adam pertama dan Adam yang kedua (Kristus). "Sifat dari tubuh kebangkitan dijelaskan oleh kontras dengan tubuh alamiah yang mengarahkan Paulus kepada kontras antara Adam dan Kristus" (15:45-49, lih Rom 5:12-21). ${ }^{15}$ Adam (Manusia pertama) dan makhlukmakhluk alamiah berasal dari debu tanah yang bersifat jasmani dan makhluk-makhluk sorgawi sama dengan Kristus berasal dari sorga (4748). Kita telah memakai rupa dari yang alamiah demikian pula kita akan memakai rupa dari yang sorgawi (49). "Tubuh itu akan sama dengan tubuh mulia Kristus sendiri” (bdg. Luk.24: 29-43; Filipi 3:21: Mazmur $17: 15){ }^{16}$

\section{Analisis Teks I Korintus 15:12-28}

Kebangkitan Kristus Adalah Dasar Kekristenan (Ayat 12-19)

Kebangkitan Kristus Diberitakan (Ayat 12)

"Jadi, bilamana kami beritakan, bahwa Kristus dibangkitkan dari antara orang mati, bagaimana mungkin ada di antara kamu yang mengatakan, bahwa tidak ada kebangkitan orang mati?." Paulus terlebih dahulu menyatakan bahwa yang diberitakan adalah kebangkitan Kristus dibangkitkan dari antara orang mati sebab rupanya ada jemaat yang menyangkal adanya kebangkitan orang mati. Dalam Alkitab Edisi Studi dituliskan, "Tampak beberapa pengikut Kristus di Korintus tidak percaya bahwa orang yang telah mati dibangkitkan dari kematian menuju kehidupan kekal." ${ }^{17}$

Dalam ayat ini terdapat pernyataan Paulus, "Jadi, bilamana kami beritakan, bahwa Kristus dibangkitkan dari antara orang mati ...." dalam teks Yunaninya, Ei de Kristos kêrussetai oti ek nekrôn egegertai. Kata

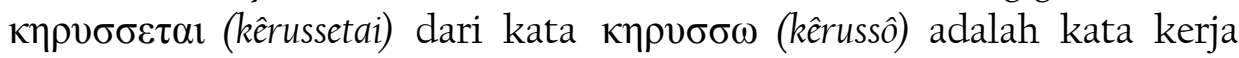

\footnotetext{
${ }^{14}$ Ibid.

${ }^{15}$ Garis Besar Surat I Korintus Dari David King, Dikutip Oleh Bob Utley "SuratSurat Paulus Kepada Sebuah Gereja Yang Bermasalah:I Dan Ii Korintus (Kumpulan Komentari Panduan Belajar, Perjanjian Baru, Vol. 8 Bible Lesson International, Marshall, Texas 1997 Revisi 2011) diakses tanggal 11 Mei 2012; tersedia di http://www.freebiblecommentary.org/pdf/ind/VOLO6_indonesian.pdf

${ }^{16}$ Charles F. Pfeiffer dan Everett F. Harrison, Tafsiran Alkitab Wiycliffe Volume 3 Perjanjian Baru (Malang: Gandum Mas, 2001), 656.

${ }^{17}$ Alkitab Edisi Studi, Cetakan Pertama (Jakarta: Percetakan Lembaga Alkitab Indonesia, 2010), 1885.
} 
present ${ }^{18}$ indikatif pasif orang ketiga tunggal. ${ }^{19}$ Kata kerja ini, menyatakan bahwa kebangkitan Kristus dari antara orang mati diberitakan oleh (dia) Paulus di mana pemberitaan atau khotbah tentang kebangkitan Kristus dari antara orang mati adalah suatu kegiatan yang tidak hanya disampaikan oleh Paulus satu kali saja. Tetapi memiliki makna kegiatan pemberitaan itu sedang dilakukannya dan terus menerus atau berulang-ulang kali dilakukannya.

Kata kerja $\varepsilon \gamma \eta \gamma \varepsilon \rho \tau \alpha \imath$ (egêgertai) dari kata $\varepsilon \gamma \varepsilon ı \omega$ (egeirô) $^{20}$ yang mempunyai arti membangkitkan (orang mati). ${ }^{21}$ Kerja yang digunakan dalam bentuk tense perfek ${ }^{22}$ indikatif pasif orang ketiga tunggal. Yang berarti bahwa (Dia) Kristus telah dibangkitkan (dihidupkan) pada masa lampau, tetapi dampaknya tetap ada hingga sekarang. Di ayat ini, digunakan kata kerja bentuk pasif bahwa Kristus yang dibangkitkan. Jadi yang membangkitkan Kristus adalah Allah sendiri. "Perfect tensenya berbicara tentang kebangkitan Yesus di masa lalu, yang menjadi suatu status keberadaan. Orang-orang percaya berbagi kenyataan kebangkitan-Nya dan oleh iman, jaminan mereka!"23

\section{Akibat Jika Tidak Ada Kebangkitan Orang Mati (Ayat 13 dan 16)}

"Kalau tidak ada kebangkitan orang mati, maka Kristus juga tidak dibangkitkan" (ayat 13). "Sebab jika benar orang mati tidak dibangkitkan, maka Kristus juga tidak dibangkitkan" (ayat 16).

Kata "kebangkitan" dalam TB (Terjemahan Baru) di ayat 13, dalam teks Yunani anastasis yang berarti bangunnya berarti peningkatan kondisi seseorang; kebangkitan (dari mati)" ${ }^{24} \mathrm{Jadi}$, orang yang mengalami kebangkitan mengalami peningkatan kondisi yang tadi mati,

\footnotetext{
${ }^{18}$ Present bentuk kata kerja yang menandakan ajakan di mana dapat muncul salah satu nuansa sebagai berikut: a). nuansa meneruskan kegiatan yang telah dimulai, dan dalam larangan menghentikan kegiatan yang sedang dilakukan; b). nuansa untuk melakukan suatu kegiatan terus menerus atau berulang kali, dan dalam larangan untuk tidak pernah melakukan kegiatan itu. B. F. Drewes, Wilfrid Haubeck, dan Heinrich von Siebenthal, Kunci Bahasa Yunani Perjanjian Baru Surat Roma Hingga Kitab Wahyu, 486.

$19 \kappa \eta \rho \sigma \sigma \varepsilon \tau \alpha$ verb indicative present passive 3rd person singular from

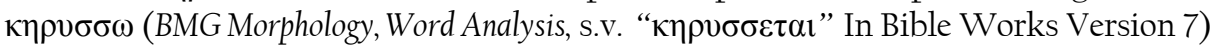

${ }^{20} \varepsilon \gamma \eta \gamma \varepsilon \rho \tau \alpha \mathrm{r}$ verb indicative perfect passive 3rd person singular from $\varepsilon \gamma \varepsilon 1 \rho \omega$

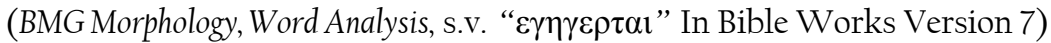

${ }^{21}$ Hasan Sutanto, Perjanjian Baru Interlinear Yunani-Indonesia dan Konkordansi Perjanjian baru, Jilid II (Jakarta: Lembaga Alkitab Indonesia, 2010), 234.

${ }^{22}$ Tense Perfekt menyatakan suatu keadaan yang sekarang ada sebagai akibat dari sesuatu yang telah dilakukan. J. W. Wenham, Bahasa Yunani Koine diterjemahkan dan disadur oleh Lynne Newell, (Malang: Seminari Alkitab Asia Tenggara, 1977), 121.

${ }^{23}$ "Surat-surat Paulus kepada Sebuah Gereja yang Bermasalah:I dan II Korintus" Bob Utley Guru Besar Hermeneutika; diakses tanggal 11-05-2012, tersedia di http://www.freebiblecommentary.org/pdf/ind/VOLO6_indonesian.pdf

${ }^{24}$ Hasan Susanto, 68.
} 
namun kemudian hidup. Terjemahan BIS (Bahasa Indonesia Sehari-hari) menggunakan kata "dihidupkan". Terjemahan KJV (King James Version), NAS (New American Standard Bible), NIV (New International Version), NKJV (New King James Version) menggunakan kata "resurrection" (kebangkitan) ${ }^{25}$

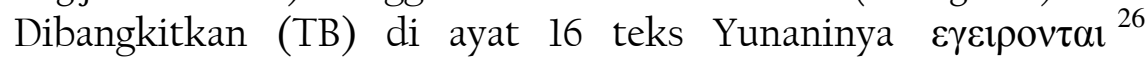
(egeirontai) dari kata $\varepsilon \gamma \varepsilon i \rho \omega$ (egeirô) membangunkan (orang tidur); bangun (dari tidur); membangkitkan (agar berdiri); membangkitkan (orang mati); mendirikan kembali; menjadikan; tampil ${ }^{27}$ Bentuk kata kerja yang digunakan adalah bentuk present indikatif ${ }^{28}$ pasif yang menjelaskan bahwa proses ini adalah realitas yang terus ada dan sedang berlanjut sampai kedatangan Kristus. Di mana Allah yang hadir dan bertindak untuk membangkitkan orang mati.

\section{Akibat Jika Kristus Tidak Dibangkitkan (Ayat 14-19) \\ Pemberitaan Menjadi Sia-Sia (Ayat 14).}

"Tetapi andaikata Kristus tidak dibangkitkan, maka sia-sialah pemberitaan kami .... " Kata "sia-sia" dalam bahasa Yunani adalah kata

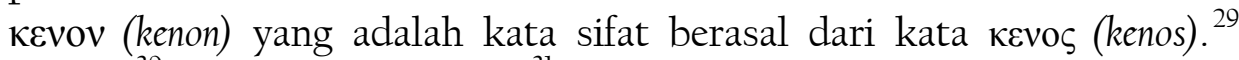
Kosong $^{30}$ hampa;sia-sia; bodoh ${ }^{31}$ dalam BIS "tidak ada gunanya". KJV, NAS, menggunkan kata "vain" yang artinya empty, vain, devoid of truth ${ }^{32}$ (kosong, sia-sia, tanpa kebenaran). Secara harfiah hampalah pemberitaan Kristen. ${ }^{33}$ "Sia-sia tidak ada apa-apanya, hampa (kenos). Andaikata tidak ada kebangkitan, Injil sama sekali tidak ada artinya. Dan iman jemaat Korintus tidak berpegang pada fakta yang nyata; semua

\footnotetext{
${ }^{25}$ Jhon M. Echols dan Hasan Shadily, Kamus Inggris Indonesia, Cetakan ke-17 (Jakarta: Gramedia Jakarta, 1989), s.v. "resurrection"

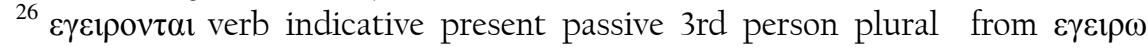

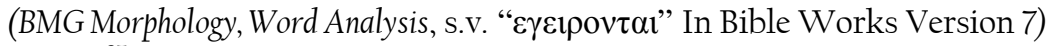

27 Hasan Susanto, Perjanjian Baru Interlinier Yunani-Indonesia dan Konkordansi Perjanjian Baru Jilid II, 234.

${ }^{28}$ Modus Indikatif (Indicative Mood), adalah modus yang menegaskan aktualitas, kepastian, atau realitas tindakan dari sudut pandang pembicara. Modus ini terdiri dari pernyataan fakta, tetapi juga dapat digunakan dalam kalimat pertanyaan ataupun negatif.

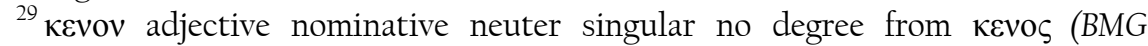
Morphology, Word Analysis, s.v. "кعvov" In Bible Works Version 7)

${ }^{30}$ Barclay M. Newman Jr, Kamus Yunani-Indonesia (Jakarta:BPK Gunung Mulia, 1991), 92. s.v “кعvov.”

${ }^{31}$ Hasan Susanto, Perjanjian Baru Interlinier Yunani-Indonesia dan Konkordansi Perjanjian Baru Jilid II (Jakarta: Lembaga Alkitab Indonesia, 2010), 444.

${ }^{32}$ Strong's Word Analysis, s.v. "vain” In Bible Works Version 7

${ }^{33}$ Victor C. Pfitzner, Ulasan Atas 1 Korintus; Kesatuan Dalam Kepelbagaian, 299.
} 
hanya khayalan belaka." ${ }^{34}$ Jadi, ayat ini mengandung pengertian bahwa penyampain berita, penyampaian khotbah atau proklamasi itu tó $\kappa \eta \rho v \gamma \mu \alpha$ (to kêrugma) ${ }^{35}$ tentang Kristus yang dibangkitkan adalah pemberitan yang sia-sia, berita itu kosong (tidak benar) jika benar Kritus tidak dibangkitkan. Pemberitaan Injil oleh para rasul di dalamnya ada peristiwa penyaliban, kematian, penguburan, dan kebangkitan Kristus. Di mana kebangkitan Kristus meneguhkan pemberitaan Injil.

\section{Kepercayaan Menjadi Sia-Sia (Ayat 14 dan 17)}

"Tetapi andaikata Kristus tidak dibangkitkan, maka ... sia-sialah juga kepercayaan kamu" (ayat 14). "Dan jika Kristus tidak dibangkitkan, maka sia-sialah kepercayaan kamu ...." (ayat 17). Dalam ayat ini pula dikatakan bahwa jika Kristus tidak dibangkitkan, ada dampak terhadap kepercayaan. Kepercayaan jemaat akan sia-sia. Sehubungan dengan frase dalam ayat ini, kenê kai ê pistis humôn. Dalam frase ini, terdapat kata kai yaitu kata penghubung yang berarti "juga." Jadi, selain pemberitaan yang menjadi sia-sia, iman atau kepercayaan juga yang menjadi sia-sia. "Semua unsur dari pemberitaan Injil dan kepercayaan yang sesuai hanya mempunyai makna dalam pertaliannya dengan pokok utama, yaitu: Kristus yang dibangkitkan. Tanpa kebangkitan itu yang lain-lain runtuh semua." ${ }^{36}$ Kata $\pi \imath \sigma \iota \varsigma$ (pistis) dari kata $\pi \imath \sigma \tau \iota \varsigma$ (pistis), ${ }^{37}$ yang berarti kepercayaan ${ }^{38}$ atau iman, kepercayaan, keyakinan, iman Kristen. ${ }^{39}$ Kata "sia-sia" di ayat ini, berbeda dengan kata yang digunakan pada ayat 14 yaitu kenos. Dalam ayat 17 menggunakan kata $\mu \alpha \tau \alpha \iota \alpha$ (mataia) dari kata

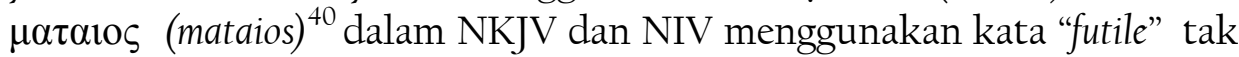
berguna; sia-sia ${ }^{41}$ (mataios) sia-sia, tanpa guna. ${ }^{42}$

\footnotetext{
${ }^{34}$ Charles F. Pfeiffer dan Everett F. Harrison, Tafsiran Alkitab Wiycliffe Volume 3 Perjanjian Baru (Malang: Gandum Mas, 2001), 652.

${ }^{35} \kappa \eta \rho \gamma \mu \alpha$ noun nominative neuter singular common from $\kappa \eta \rho \vartheta \gamma \mu \alpha$ (BMG

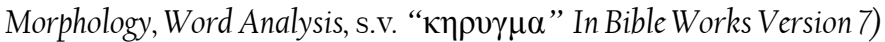

${ }^{36}$ Jerusalem (I Korintus 15:14), diakses tanggal 26-04-2012 tersedia di http://alkitab.sabda.org/commentary.php?passage=1Kor\%2015:12-34.

${ }^{37} \pi 1 \sigma \tau \iota \varsigma$ noun nominative feminine singular from $\pi \iota \tau \tau \iota$ (BMG Morphology, Word Analysis, s.v. “ $\pi \imath \tau \imath \iota$ ” In Bible Works Version 7)

${ }^{38}$ Hasan Sutanto, Perjanjian Baru Interlinear Yunani-Indonesia dan Konkordansi Perjanjian baru, Jilid I, (Jakarta: Lembaga Alkitab Indonesia, 2010), 944.

${ }^{39}$ Barclay M. Newman Jr, Kamus Yunani-Indonesia, 17l. s.v “ $\pi \iota \tau \imath \iota "$

${ }^{40} \mu \alpha \tau \alpha \iota \alpha$ adjective nominative feminine singular no degree from $\mu \alpha \tau \alpha 10 \varsigma$ (BMG Morphology, Word Analysis, s.v. " $\mu \alpha \tau \alpha \iota \alpha$ " In Bible Works Version 7)

${ }^{41}$ Peter Salim, Advanced English-Indonesia Dictionary, (Jakarta: Modern English Press, 1989), s.v. "futile"
} 


\section{Berdusta Terhadap Allah (Ayat 15)}

Kata pseudomartures dari kata pseudomartus ${ }^{43}$ yang berarti saksisaksi palsu. ${ }^{44}$ Dan sehubungan dengan frase emarturesamen kata tou theou, kata emarturêsamen dari kata martureô $\hat{o}^{45}$ yang berarti "memberi kesaksian; menjadi saksi; membuktikan; mengatakan baik; membuktikan baik.."46 Bentuk kata kerja yang digunakan dalam ayat ini adalah aorist indikatif aktif orang pertama jamak. Jadi, pengertian dari ayat ini adalah jika benar tidak ada kebangkitan orang mati, Paulus menyatakan dirinya dan para pemberita Injil (kami) adalah saksi-saksi palsu yang telah menyampaikan kesaksian palsu yang melawan Allah dengan menyampaikan hal yang tidak benar tentang Allah yang telah membangkitkan Kristus.

\section{Orang Percaya Masih Hidup Dalam Dosa (Ayat 17)}

"Dan jika Kristus tidak dibangkitkan, maka ... kamu masih hidup dalam dosamu" (ayat 17). Dalam ayat ini Paulus juga menyatakan suatu akibat yang akan membuat iman Kristen goyah jika Kristus tidak dibangkitkan. Jika memang benar Kristus tidak dibangkitkan, maka peristiwa penebusan oleh Kristus melalui pengorbanan-Nya gagal. Menurut Donald Guthrie, "Seandainya Kristus tidak dibangkitkan, maka tidak akan nada kepastian bahwa kematian-Nya telah menghasilkan sesuatu apapun. Seperti yang dikatakan oleh Paulus, manusia akan tetap tinggal dalam dosa-dosanya (I Korintus 15:17). ${ }^{47}$

\section{Orang yang Mati Dalam Kristus Binasa (Ayat 18)}

"Demikianlah binasa juga orang-orang yang mati dalam Kristus" (ayat 18). Akibat lainnya jika Kritus tidak dibangkitkan adalah orangorang percaya atau orang-orang yang mati dalam Kristus mengalami kebinasaan. "Ayat ini memuat akibat lain yang akan mengikuti, jika

\footnotetext{
${ }^{42}$ B. F. Drewes, Wilfrid Haubeck, dan Heinrich von Siebenthal, Kunci Bahasa Yunani Perjanjian Baru Surat Roma Hingga Kitab Wahyu (Jakarta: BPK Gunung Mulia, 2010), 96.

${ }^{43}$ pseudomartures noun nominative masculine plural common from pseudomartus (BMG Morphology, Word Analysis, s.v. "pseudomartures" In Bible Works Version 7)

${ }^{44}$ Hasan Susanto, Perjanjian Baru Interlinier Yunani-Indonesia dan Konkordansi Perjanjian Baru Jilid II , 944.

${ }^{45}$ emarturêsamen adalah verb indicative aorist active lst person plural from martureô (BMG Morphology, Word Analysis, s.v. "emarturêsamen” In Bible Works Version 7)

${ }^{46}$ Hasan Susanto, Perjanjian Baru Interlinier Yunani-Indonesia dan Konkordansi Perjanjian Baru Jilid II, 502.

${ }^{47}$ Donald Guthrie, Teologi Perjanjian Baru 1 (Jakarta: BPK Gunung Mulia, 1992), 446.
} 
Kritus tidak dibangkitkan, yaitu orang-orang yang mati dalam Kristus tidak selamat." ${ }^{48}$ Kata yang digunakan dalam kalimat ini adalah apôlonto dari kata apollumi ${ }^{49}$ yang berarti membinasakan; membunuh; mati; menuju kebinasaan; kehilangan; hilang; rusak; terbuang; tersesat. ${ }^{50}$

\section{Orang-orang Percaya Adalah Orang Paling Malang (Ayat 19)}

Kata pengharapan (TB) dalam bahasa Yunani êlpikotes dari kata elpizo ${ }^{51}$ yang berarti berharap; mengharapkan ${ }^{52}$ Kata kerjanya adalah kata kerja bentuk perfekt participle active yang berarti kita adalah orangorang percaya yang telah mengambil keputusan mengharapkan Kristus atau yang berharap kepada Kristus, mengakibatkan kita hingga sekarang menjadi orang-orang yang malang. Dan kata "malang" dalam TB dalam bahasa Yunaninya eleeinoteroi adalah kata sifat dari kata eleeinos. ${ }^{53}$

Jadi, eleeinoteroi bisa berarti, sangat menyedihkan (most miserable), dalam kamus bahasa Inggris, pitiable adalah, "yang menimbulkan belas kasihan" ${ }^{54}$ pitied "patut dikasihani." ${ }^{55}$ Kesimpulannya ialah jika Kristus tidak dibangkitkan maka kita yang telah menaruh pengharapanya pada Kristus menjadi orang-orang yang sangat menyedihkan, patut dikasihani.

\section{Kebangkitan Kristus Adalah Dasar Kebangkitan Orang Percaya (Ayat 20-23) Kebangkitan Kristus (Ayat 20)}

Kata "dibangkitkan" menggunakan kata kerja yang sama dengan yang digunakan pada ayat 12 yaitu kata egêgertai dalam bentuk perfect, indikatif, ${ }^{56}$ pasif, orang ketiga tunggal. Berarti (Dia) Kristus dibangkitkan oleh Allah sendiri dan kebangkitan-Nya itu memiliki

\footnotetext{
${ }^{48}$ David Ibrahim, Pelajaran Surat I Korintus, 259.

${ }^{49}$ apôlonto verb indicative aorist middle 3 rd person plural from apollumi (BMG Morphology, Word Analysis, s.v. "apôlonto" In Bible Works Version 7)

${ }^{50}$ Hasan Susanto, Perjanjian Baru Interlinier Yunani-Indonesia dan Konkordansi Perjanjian Baru Jilid II, 102.

${ }^{51}$ êlpikotes verb participle perfect active nominative masculine plural from elpizo (BMG Morphology, Word Analysis, s.v. “êlpikotes” In Bible Works Version 7)

${ }^{52}$ Hasan Susanto, Perjanjian Baru Interlinier Yunani-Indonesia dan Konkordansi Perjanjian Baru Jilid II, 270.

${ }^{53}$ eleeinoteroi adjective normal nominative masculine plural comparative from eleeinos (BMG Morphology, Word Analysis, s.v. "eleeinoteroi" In Bible Works Version 7)

${ }^{54}$ Jhon M. Echols dan Hasan Shadily, Kamus Inggris Indonesia, Cetakan Ke-17 (Jakarta: Gramedia Jakarta, 1989), s.v. "pitiable"

${ }^{55} \mathrm{Ibid}$, s.v. "pitied lihat kata pity".

${ }^{56}$ Modus Indikatif (Indicative Mood), adalah modus yang menegaskan aktualitas, kepastian, atau realitas tindakan dari sudut pandang pembicara.
} 
pengaruh atau dampak bagi orang percaya baik masa sekarang maupun

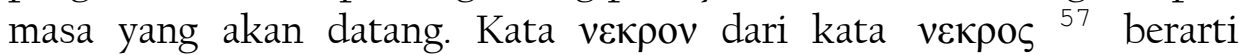

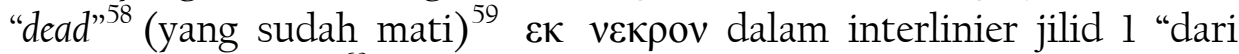
orang-orang mati." ${ }^{60}$ Timotius Subekti mengatakan, "Kebangkitan di dalam bahasa Gerika disebut: "ek nekron"=out resurrection" yang diterjemahkan ke dalam bahasa Indonesia "kebangkitan dari antara orang mati yang berarti dibangkitkan pada saat orang-orang lainnya masih mati." ${ }^{61}$ Walaupun Kristus juga sempat mengalami kematian tubuh, namun telah dibangkitkan dari antara orang-orang yang sudah mati. Hal yang hakiki berikutnya yaitu, Kristus sebagai yang sulung. Kata "sulung" dalam bahasa Yunani adalah aparchê dari kata aparch $\hat{e}^{62}$ yang memiliki makna buah sulung (menunjuk bagian pertama, termasuk dari hewan, yang dikhususkan bagi Allah); buah sulung berarti sebagian dulu atau yang pertama. ${ }^{63}$ Dalam KJV, NIV, NAS, "the first fruits" (buah pertama).

Jadi Kristus sebagai yang sulung atau yang pertama mewakili semua orang percaya yang akan dibangkitkan. Sebab, melalui kebangkitan Kristus dari antara orang mati, memberikan pengharapan serta jaminan bagi umat-Nya. Kristus telah terlebih dahulu dibangkitkan dan kemudian orang-orang percaya pada masa yang akan datang.

\section{Kematian Umat Manusia Dalam Persekutuan Dengan Adam (Ayat 21-22)}

Kematian tubuh disebabkan oleh satu orang manusia (Adam) dalam teks Yunaninya adalah anthrôpou dari kata anthrôpos (kata benda genitive masculine tunggal) yang berarti manusia; orang; laki-laki (dewasa) ${ }^{64}$ dalam ayat yang ke 22 dituliskan "Karena sama seperti semua orang mati dalam persekutuan dengan Adam." Kata apothnêskousin di

\footnotetext{
${ }^{57}$ nekron adjective normal genitive masculine plural no degree from nekros (BMG Morphology, Word Analysis, s.v. "nekron” In Bible Works Version 7)

${ }^{58}$ The New Strong's Exhaustive Concordance of the Bible, s.v. "nekron"

${ }^{59}$ Jhon M. Echols dan Hasan Shadily, Kamus Inggris Indonesia, Cetakan Ke-17 (Jakarta: Gramedia Jakarta, 1989), s.v. "dead".

${ }^{60}$ Hasan Susanto, Perjanjian Baru Interlinier Yunani-Indonesia dan Konkordansi Perjanjian Baru Jilid I, 944.

${ }^{61}$ Timotius Subekti, Kesucian (Yogyakarta: Penerbit ANDI, 1986), 130.

${ }^{62}$ aparchê noun nominative feminine singular common from aparchê (BMG Morphology, Word Analysis, s.v. "aparchê" In Bible Works Version 7)

${ }^{63}$ Hasan Susanto, Perjanjian Baru Interlinier Yunani-Indonesia dan Konkordansi Perjanjian Baru Jilid II, 91.

${ }^{64}$ Hasan Susanto, Perjanjian Baru Interlinier Yunani-Indonesia dan Konkordansi Perjanjian Baru Jilid II, 75.
} 
ayat ini, dari kata apothnêsk $\hat{o}^{65}$ yang berarti tidak dapat berespons; kehilangan hidup kekal; berhadapan dengan maut. ${ }^{66}$ Bentuk kata kerja yang digunakan adalah present indikatif aktif orang ketiga jamak dalam ayat ini Paulus menyatakan bahwa mereka yang ada dalam persekutuan dengan Adam sedang mengalami kematian. Dengan maksud bahwa, karena upah dosa sehingga mengakibatkan kematian jasmani dialami oleh manusia.

\section{Kehidupan Dalam Persekutuan Dengan Kristus (Ayat 22)}

Kata zôopoiêthêsontai dari kata zôopoieô ${ }^{67}$ menghidupkan; memberikan hidup kepada. ${ }^{68}$ Kata kerja yang dipakai adalah kata kerja bentuk future ${ }^{69}$ pasif. Jadi, mereka yang mati karena dalam persekutuan dengan Adam, akan dihidupkan kembali atau akan diberikan kehidupan bagi semua orang yang hidup di dalam persekutuan dengan Kristus pada masa yang akan datang (ini menyangkut parousia yaitu pada kedatangan Kristus di ayat 23) dan tentunya yang memberikan hidup adalah Allah sendiri bagi orang yang ada di dalam persekutuan dengan Kristus.

\section{Kristus Sebagai Buah Sulung (Ayat 23)}

Dalam ayat 23 kata buah sulung sama juga yang digunakan pada ayat 20 yaitu (aparchê). Kristus adalah sebagai buah sulung dari kebangkitan itu. Buah sulung mewakili seluruh hasil tuaian yang dinantikan dan yang masih akan dikumpulkan. Herman Ridderbos mengatakan, "Karena kebangkitan Kristus bagi masa depan umat-Nya ini memiliki makna yang sedemikian menyeluruh, maka Kristus juga disebut sebagai buah sulung (aparche) dari mereka yang telah meninggal (I Korintus 15:20, 23)."

\section{Kebangkitan Orang Percaya (Ayat 23)}

"Tetapi tiap-tiap orang menurut urutannya ... sesudah itu mereka yang menjadi milik-Nya pada waktu kedatangan-Nya." Dalam teks

\footnotetext{
${ }^{65}$ apothnêskousin verb indicative present active 3rd person plural from apothnêskô (BMG Morphology, Word Analysis, s.v. “apothnêskousin” In Bible Works Version 7)

${ }^{66}$ Hasan Susanto, Perjanjian Baru Interlinier Yunani-Indonesia dan Konkordansi Perjanjian Baru Jilid II, 98.

${ }^{67}$ zôopoiêthêsontai verb indicative future passive 3 rd person plural from zôopoieô (BMG Morphology, Word Analysis, s.v. "zôopoiêthêsontai" In Bible Works Version 7)

${ }^{68}$ Hasan Susanto, Perjanjian Baru Interlinier Yunani-Indonesia dan Konkordansi Perjanjian Baru Jilid II, 343.

${ }^{69}$ Future menggambarkan tindakan yang akan terjadi di masa yang akan datang. William D. Mounce, Basic of Biblical Greek; Dasar-dasar Yunani Biblika, (Malang: Literartur Saat, 2011), 133.

${ }^{70}$ Herman Ridderbos, Paulus: Pemikiran Utama Theologinya, 568.
} 
Yunaninya epeita oi tou Kristou en tê parousia autou. Sesuai dengan urutan yang dijelaskan oleh Paulus bahwa Kristus yang pertama sesudah itu orang-orang yang menjadi kepunyaan-Nya pada waktu kedatangan Kritus. Dalam terjemahan KJV (King James Version), "afterward they that are Christ's at His coming" frase ini dalam terjemahan bebas "Setelah itu mereka yang adalah milik Kristus pada kedatangan-Nya. Dan dalam terjemahan NIV (New English Version) "then, when he comes, those who belong to him." Dalam terjemahan bebas, "Kemudian, ketika Dia datang, mereka kepunyaanNya." Dalam KJV, NKJV, NAS menggunakan kata "coming” yang berarti presence, arrival, advent, the coming ${ }^{71}$ kehadiran, tibanya, datangnya ${ }^{72}$ kedatangan.

Kata autou dari kata autos $^{73}$ diri; sendiri; ia ${ }^{74}$ yaitu Kristus sendiri yang dalam kalimat ini menggunakan kasus genetif yang bermakna kepunyaan (kedatangan Kristus). Jadi, orang-orang yang menjadi milik Kritus akan mengalami kebangkitan pada saat kedatangan Kristus di mana Kristus Ia menyatakan kemuliaan-Nya. Kebangkitan orang-orang percaya atau yang menjadi milik Kristus untuk memperoleh kehidupan kekal. Kebangkitan orang yang menjadi milik Kristus tidak dapat dipisahkan dengan kehidupan kekal yang akan diperolehnya.

\section{Kemenangan Kristus dan Pemerintahan-Nya (Ayat 24-28)}

Di dalam kebangkitan Kristus setelah kebangkitan-Nya sebagai yang sulung, dan kemudian akan disusul oleh kebangkitan orang percaya pada waktu kedatangan-Nya.

Sejak kebangkitan Kristus Ia sudah memperoleh kemenangan seperti yang dikatakan oleh J.Knox Chamblin "Inti tujuan pemerintahan Kristus yang telah dimulai adalah kemenangan atas semua musuh-Nya dan musuh umat-Nya" (I Korintus 15: 20-28)..$^{95}$

\section{Menyerahkan Kerajaan Kepada Allah Bapa (Ayat 24)}

"Kemudian tiba kesudahannya, yaitu bilamana Ia menyerahkan Kerajaan kepada Allah Bapa, ...." (ayat 24). BIS menggunakan kalimat "Sesudah itu terjadilah kiamat." Dalam teks Yunani kata menyerahkan

\footnotetext{
${ }^{71}$ Strong's Word Analysis, s.v. “coming” In Bible Works Version)

${ }^{72}$ Jhon M. Echols dan Hasan Shadily, Kamus Inggris-Indonesia, Cetakan Ke-17 (Jakarta: Gramedia Jakarta, 1989), s.v. "presence, arrival, advent".

${ }^{73}$ autou pronoun personal genitive masculine singular from autos (BMG Morphology, Word Analysis, s.v. “autou” In Bible Works Version 7)

${ }^{74}$ Hasan Susanto, Perjanjian Baru Interlinier Yunani-Indonesia dan Konkordansi Perjanjian Baru Jilid II, 129. Jenis maskulin, kategori jumlah singularis, kasus nominatif.

${ }^{75}$ J. Knox Chamblin, Paulus dan Diri: Ajaran Rasuli Bagi Keutuhan Pribadi, 81.
} 
adalah paradidô dari kata paradidômi ${ }^{76}$ yang berarti menyerahkan, meneruskan. ${ }^{77}$ Dan kata kerja yang digunakan adalah bentuk present aktif orang ketiga tunggal modus subjungtif ${ }^{78}$ Berarti proses pemerintahan itu berlanjut. Dengan maksud bahwa, pemerintahan Kristus yang sekarang akan diserahkan kepada Allah Bapa secara terus menerus (dari Kristus kemudian kepada Allah Bapa). Di mana proses pemerintahan Allah dalam Kerajaan-Nya, berlangsung untuk selamalamanya.

\section{Kristus Membinasakan Pemerintahan, Kekuasaan, dan Kekuatan}

"Kemudian tiba kesudahannya ... sesudah Ia membinasakan segala pemerintahan, kekuasaan, dan kekuatan" (ayat 24). Kristus menyerahkan Kerajaan Allah kepada Bapa setelah Kristus membinasakan pemerintahan, kekuasaan dan kekuatan. Dari ketiga yang dibinasakan ini adalah hal-hal yang 'supernatural ${ }^{79}$ Kata membinasakan katargêsê berasal dari kata katarge $\hat{o}^{80}$ yang berarti "membatalkan; membinasakan; mematahkan." ${ }^{\text {81 }}$ Dari kata kerja ini menggunakan bentuk aorist ${ }^{82}$ aktif orang ketiga tunggal modus subjunktif yang menunjukkan bahwa Kristus yang telah (pernah) membinasakan segala pemerintahan, kekuasan dan kekuatan melalui peristiwa kebangkitan-Nya. Dan sebelum Kristus menyerahkan Kerajaan kepada Allah Bapa, penghancuran total itu mencapai puncak atau akhirnya.

\section{Kristus Harus Memegang Pemerintahan Sebagai Raja (Ayat 25)}

"Karena Ia harus memegang pemerintahan sebagai Raja sampai Allah meletakkan semua musuh-Nya di bawah kaki-Nya" (ayat 25). Setelah Paulus mengemukakan tentang kesudahan atau suatu masa dimana kerajaan Allah yang diserahkan kepada Allah Bapa setelah Kristus mengalahkan segala, pemerintahan, kekuasaan, dan kekuatan, ia

\footnotetext{
${ }^{76}$ paradidô verb subjunctive present active $3 \mathrm{rd}$ person singular from paradidomi (BMG Morphology, Word Analysis, s.v. "paradidô” In Bible Works Version 7).

77 Hasan Susanto, Perjanjian Baru Interlinier Yunani-Indonesia dan Konkordansi Perjanjian Baru Jilid II, 605.

${ }^{78}$ Sebuah verba dalam subjungtif kala sekarang mengindikasikan tindakan yang kontinu.William D. Mounce, Basic of Biblical Greek; Dasar-dasar Yunani Biblika 237.

${ }^{79}$ Hasan Susanto, Perjanjian Baru Interlinier Yunani-Indonesia dan Konkordansi Perjanjian Baru Jilid I, 945.

${ }^{80}$ katargêsê verb subjunctive aorist active 3rd person singular from katargeô (BMG Morphology, Word Analysis, s.v. "katargêsê" In Bible Works Version 7)

${ }^{81}$ Barclay M. Newman Jr, Kamus Yunani-Indonesia (Jakarta: BPK Gunung Mulia, 1991), 88. s.v "katargêsê"

${ }^{82}$ Maksud Tense Aorist adalah untuk menyatakan bahwa sesuatu hal pernah terjadi atau pernah dilakukan. J.W. Wenham, Bahasa Yunani Koine diterjemahkan dan disadur oleh Lynne Newell, (Malang: Seminari Alkitab Asia Tenggara, 1977), 77.
} 
selanjutnya menjelaskan alasan atau penyebab. Dalam teks Yunani dei gar auton basileuein. Kata dei yang berasal dari kata dei ${ }^{83}$ yang berarti "harus; patut $^{84}$ dalam bentuk kata kerja present aktif, orang ketiga tunggal. Dan kata basiliuein dari kata basileuô ${ }^{85}$ yang juga adalah kata kerja kerja present aktif infinitif. ${ }^{86}$ Dalam KJV, NAS, NIV, NKJV, "For he must reign" kata "reign" berarti "to be king" ${ }^{\prime 87}$ (menjadi raja). Dia (Kristus) sekarang harus memegang pemerintahan sebagai Raja. "Proses ini telah dimulai di dalam Adam kedua, yaitu Dia yang membalikkan keberadaan dosa dalam dunia dan melakukan itu juga bagi masing-masing kita setiap hari. Hal ini terjadi karena pernyataan kuasanya demi menebus kita dari kutukan dosa.

\section{Musuh Terakhir yang Dibinasakan Adalah Maut (Ayat 26)}

"Musuh yang terakhir, yang dibinasakan ialah maut" (ayat 26). Pada ayat 25 dikatakan bahwa Allah menaklukkan semua musuhmusuh-Nya. Dalam ayat ini maut adalah salah satu musuh, dan disebutkan musuh terakhir yang dibinasakan. Frase "musuh yang terakhir" dalam KJV, NIV, NAS, NKJV,"The last enemy" (musuh terakhir). Maut adalah salah satu dari musuh-musuh yang ditaklukkan oleh Kristus. Maut adalah yang terakhir dibinasakan pada waktu atau masa kesudahan itu. Kata musuh dalam teks Yunani echthros dari kata echthros ${ }^{89}$ yang adalah kata sifat yang berarti "yang bermusuhan; yang

\footnotetext{
${ }^{83}$ dei verb indicative present active 3rd person singular from dei (BMG Morphology, Word Analysis, s.v. "dei” In Bible Works Version 7)

${ }^{84}$ Barclay M. Newman Jr, Kamus Yunani-Indonesia (Jakarta: BPK Gunung Mulia, 1991), 36. s.v "dei"

${ }^{85}$ basiliuein verb infinitive present active from basileuô (BMG Morphology, Word Analysis, s.v. "basiliuein" In Bible Works Version 7)

${ }^{86}$ Infinitif bahasa Yunani memiliki kala, sesuatu yang tidak jelas dalam infinitif bahasa Inggris. Kala dalam ayat ini adalah kala sekarang, yang menggambarkan tindakan kontinu. Karena itu infinitif kala sekarang menjelaskan apa yang penting mengenai apa yang Allah sedang lakukan melalui Yesus. (Kala menekankan jenis tindakan). Maka Paulus menekankan bahwa Yesus sedang dalam proses memerintah sampai pekerjaan menaklukkan segala sesuatu digenapi. Darell L.Bock dikutip oleh William D. Mounce, Basic of Biblical Greek; Dasar-dasar Yunani Biblika, (Malang: Literartur Saat, 2011), 245.Modus infinitif (Infinitive Mood). Infinitif dapat dipakai untuk menyatakan tujuan ataupun hasil dari suatu tindakan."5795>-Nomor Strong YunaniAlkitab SABDA", diakses 28-06-2012; tersedia di http://alkitab.sabda.org/strong.php?id=5795.

${ }^{87}$ Strong's Word Analysis, s.v. "reign" In Bible Works Version 7

${ }^{88}$ William D. Mounce, Basic of Biblical Greek; Dasar-dasar Yunani Biblika, (Malang: Literartur Saat, 2011), 245.

${ }^{89}$ echthros adjective normal nominative masculine singular no degree from echthros (BMG Morphology,Word Analysis, s.v. "echthros" In Bible Works Version 7)
} 
dibenci; musuh". 90 Dalam Terjemahan Baru (TB) musuh terakhir adalah maut. Dalam BIS menggunakan kata kematian dalam teks Yunaninya menggunakan kata thanatos dari kata thanatos ${ }^{91}$ dan dalam KJV, NAS, NIV, dan NKJV menggunakan kata "death" yang berarti "the death of the body "92 (kematian tubuh). Jadi, musuh terakhir dari semua musuh yang ditaklukkan oleh Allah adalah kematian tubuh yang pada akhirnya juga dibinasakan. Kematian tubuh tidak akan ada lagi ketika Kristus datang kembali (parousia) di masa kesudahan tersebut. Kata "dibinasakan" (TB) dan NAS (New American Standard Bible) menggunakan kata "abolished" (dihapuskan). Di ayat ini kembali menggunakan kata katargeitai dari kata katarge $\hat{o}^{93}$ seperti pada ayat 24 yang berarti menghentikan, meniadakan, berhenti. $^{94}$ Sesuai dengan kata kerja yang digunakan adalah present indikatif ${ }^{95}$ pasif orang ketiga tunggal. Jadi, maut yang telah ditaklukkan melalui kebangkitan Kristus, sedang ada dalam proses penghapusan yang pada akhirnya akan mengalami puncaknya di akhir zaman. Maut telah ditaklukkan kuasanya ketika Kristus dibangkitkan namun pada akhirnya atau puncaknya, secara terang-terangan maut dibinasakan dihapuskan, di mana kematian akan berhenti untuk selamanya.

\section{Segala Sesuatu Telah Ditaklukkan-Nya (Ayat 27)}

"Sebab segala sesuatu telah ditaklukkan-Nya di bawah kaki-Nya" (ayat 27a). Allah telah menaklukkan segala sesuatu di bawah kaki-Nya. Allah menunjukkan bahwa Ia berkuasa atas segala sesuatu. Dari ayat sebelumnya bahwa Allah sendirilah yang meletakkan semua musuhmusuh-Nya di bawah kaki Kristus.Dalam teks Yunaninya hupetaxen dari kata hupotassô ${ }^{96}$ artinya "menundukkan, menaklukkan." ${ }^{97}$ Kata kerjanya

\footnotetext{
${ }^{90}$ Hasan Susanto, Perjanjian Baru Interlinier Yunani-Indonesia dan Konkordansi Perjanjian Baru Jilid II, 335.

${ }^{91}$ thanatos noun nominative masculine singular common from thanatos (BMG Morphology, Word Analysis, s.v. "thanatos" In Bible Works Version 7)

${ }^{92}$ Strong's Word Analysis, S.V. "( is) death" In Bible Works Version 7

${ }^{93}$ katargeitai dari kata verb indicative present passive $3 \mathrm{rd}$ person singular from katargeô.

${ }^{94}$ Hasan Susanto, Perjanjian Baru Interlinier Yunani-Indonesia dan Konkordansi Perjanjian Baru Jilid II, 437.

${ }^{95} \mathrm{Pada}$ dasarnya verba aktif indikatif kala sekarang, dalam bahasa Yunani, sama seperti dalam bahasa Inggris. Ia menggambarkan sebuah tindakan yang biasanya terjadi pada waktu sekarang. Bisa sebagai tindakan kontinu. Mounce, Basic of Biblical Greek; Dasar-dasar Yunani Biblika, 113.

${ }^{96}$ hupetaxen verb indicative aorist active 3rd person singular from hupotassô (BMG Morphology, Word Analysis, s.v. "hupetaxen" In Bible Works Version 7)

${ }^{97}$ Barclay M. Newman Jr, Kamus Yunani-Indonesia (Jakarta: BPK Gunung Mulia, 1991), 180. s.v. hupotassô.
} 
dalam bentuk aorist aktif indikatif orang ketiga tunggal, yang menyatakan bahwa, Allah sendiri (Ia) telah menaklukkan segala sesuatu di bawah kaki-Nya "Segala sesuatu menunjuk pada 'semua musuh-Nya' dalam ayat sebelumnya (ayat 25)." ${ }^{98}$ Dalam konteks ini, musuh-musuh di sini adalah mencakup semua pemerintahan, kekuasaan dan kekuatan (ayat 24) termasuk maut yang disebutkan sebagai musuh terakhir yang dibinasakan (ayat 26).

"Tetapi kalau dikatakan, bahwa "segala sesuatu telah ditaklukkan", maka teranglah, bahwa Ia sendiri yang telah menaklukkan segala sesuatu di bawah kaki Kristus itu tidak termasuk di dalamnya" (ayat 27b). Kata "but"(tetapi) yang berfungsi sebagai kata sambung yang menunjukkan kontras pada pernyataan sebelumnya. Paulus mengatakan bahwa segala sesuatu telah ditaklukkan. Kata "tetapi" di sini mempertentangkan bahwa Allah tidak termasuk di dalam segala sesuatu tersebut yang ditaklukkan di bawah kaki Kristus. Sebab yang meletakkan dan menakklukkan "segala sesuatu" di bawah kaki Kristus tersebut adalah Allah sendiri. Di sini, pengecualian dari penaklukkan terhadap segala sesuatu tersebut berlaku pada Allah. Dalam BIS dikatakan, "Jelaslah bahwa yang dimaksud dengan 'segala sesuatu' itu tidak termasuk Allah sendiri, yang membuat segala takluk kepada Kristus." "Segala sesuatu telah ditaklukkan." Kata ditaklukkan (TB) dalam teks Yunaninya hupotetaktai juga dari kata hupotassô. ${ }^{99}$ Namun, bentuk kata kerja yang dipakai di sini berbeda dengan kata kerja yang sebelumnya. Kata kerja yang digunakan di sini adalah kata kerja bentuk perfek ${ }^{100}$ indikatif pasif orang ketiga tunggal. Dalam Interlinier jilid I "telah menjadi takluk". 101 Jadi, penaklukkan yang telah dilakukan oleh Allah, terhadap segala sesuatu dan musuh-musuh-Nya di bawah kaki Kristus, terus berdampak sampai saat ini dan untuk selama-lamanya (sekali untuk selamanya).

\section{Supaya Allah Menjadi Semua di Dalam Semua (Ayat 28)}

"Tetapi kalau segala sesuatu telah ditaklukkan di bawah Kristus, maka Ia sendiri sebagai Anak akan menaklukkan diri-Nya di bawah Dia, yang telah menaklukkan segala sesuatu di bawah-Nya, supaya Allah menjadi semua di dalam semua" (ayat 28). Pada ayat sebelumnya jelas

\footnotetext{
${ }^{98}$ Pfitzner, Ulasan Atas 1 Korintus; Kesatuan Dalam Kepelbagaian, 308.

${ }^{99}$ hupotetaktai verb indicative perfect passive 3rd person singular from hupotassô (BMG Morphology, Word Analysis, s.v. "hupotetaktai" In Bible Works Version 7)

${ }^{100}$ Perfect Tense menyatakan suatu keadaan yang sekarang ada sebagai akibat dari suatu yang telah dilakukan (a present state resulting from apast action); suatu tindakan yang telah rampung di masa lampau tanpa memerlukan tindakan ulang, dengan hasil yang positif dan pasti di masa kini.

${ }^{101}$ Hasan Susanto, Perjanjian Baru Interlinier Yunani-Indonesia dan Konkordansi Perjanjian Baru Jilid I, 945.
} 
bahwa Allah yang menakklukkan segala sesuatu di bawah kaki Kristus, dan oleh sebab itu "Anak akan menaklukkan diri-Nya di bawah Dia." Kata menaklukkan di sini adalah hupotagesetai juga dari kata hupotassô yang bisa juga berarti menundukkan namun kata kerjanya dalam bentuk future indikatif pasif orang ketiga tunggal dalam pengertian bahwa Anak akan ditundukkan di bawah Dia (Allah). Ini kembali dihubungkan dengan ayat 24 dimana setelah menaklukkan musuh-musuh-Nya, Ia menyerahkan Kerajaan kepada Bapa. Ini menyatakan pemerintahan Allah Tritunggal setelah Kristus sebagai Putra yang menjelma memerintah dan menaklukkan musuh-musuh-Nya kemudian menyerahkan pemerintahan tersebut kepada Bapa pada masa kesudahan. Setelah Kristus menggenapi dan melaksanakan semua tugas dari sang Bapa maka Ia menyerahkan kerajaan itu kepada Bapa, dengan demikian Allah Tritungal dalam Kerajaan-Nya memerintah dan berkuasa untuk selama-lamanya.

\section{IMPLIKASI MAKNA KEBANGKITAN KRISTUS BAGI ORANG PERCAYA}

\section{Kebangkitan Kristus Dengan Pemberitaan Injil}

Seperti yang disampaikan oleh Paulus sendiri dalam I Korintus 15:2 kepada jemaat Korintus bahwa oleh Injillah kamu diselamatkan. Orangorang percaya harus menyadari bahwa kebangkitan Kristus meneguhkan pemberitaan Injil. Pemberitaan tentang kelahiran, kehidupan, dan kematian Kristus belum cukup tanpa pemberitaan kebangkitan Kristus, berarti penyampaian Injil itu tidak utuh. Orang-orang percaya harus menyadari pentingnya berita Injil yang lengkap. Rasul Paulus mengatakan, "Sebab yang sangat penting telah kusampaikan kepadamu, yaitu apa yang telah kuterima sendiri, ialah bahwa Kristus telah mati karena dosa-dosa kita, sesuai dengan Kitab Suci, bahwa Ia telah dikuburkan, dan bahwa Ia telah dibangkitkan, pada hari yang ketiga, sesuai dengan Kitab Suci (I Korintus 15: 3-4). Itulah berita Injil yang utuh yang disampaikan oleh Paulus. Selanjutnya Ia mengatakan, "Jadi, bilamana kami beritakan, bahwa Kristus dibangkitkan dari antara orang mati .... "(I Korintus 15:12). "Tetapi andaikata Kristus tidak dibangkitkan, maka sia-sialah pemberitaan kami .... " (I Korintus 15:14). Jadi, Paulus menyampaikan Injil yang di dalamnya ada pemberitaan tentang Kristus yang dibangkitkan.

Demikian juga bagi orang-orang percaya pada zaman ini bahwa pemberitaan Injil itu harus terus menerus dilakukan. Gereja berkewajiban melakukan tugasnya sebagai saksi-saksi Kristus. J. L. Ch. Abineno mengatakan, "Kebangkitan Yesus mempunyai hubungan yang 
erat dengan pengutusan (=apostolat) gereja. Kuasa kebangkitan-Nya bukan saja membuat murid-murid percaya, tetapi kuasa itu juga mendorong mereka ke luar ke dalam dunia untuk menjadi saksi-saksiNya. ${ }^{102} \mathrm{Jadi}$, orang-orang yang menjadi murid Kristus bukan hanya mengenal akan karya penyelamatan Allah melalui Tuhan Yesus Kristus, tetapi berkewajiban untuk memberitakan karya Allah di dalam Injil keselamatan bagi mereka yang belum percaya kepada Kristus.

\section{Kebangkitan Kristus Dengan Iman Kristen}

Salah satu bagian dalam kekristenan yang sangat berkaitan dengan kebangkitan Kristus adalah iman Kristen. "Iman adalah dasar dari segala sesuatu yang kita harapkan dan bukti dari segala sesuatu yang tidak kita lihat" (Ibrani 1l: 1). Orang-orang percaya harus mengerti bahwa beriman memiliki landasan yang jelas. Seperti yang dikatakan oleh R.C. Sproul, "Akar dari istilah iman adalah 'percaya'. Percaya kepada Allah bukan merupakan suatu tindakan yang berdasarkan pada kepercayaan yang tidak beralasan. Allah menyatakan Diri-Nya sendiri sebagai Pribadi yang patut dipercayai. Dia memberikan alasan yang cukup bagi kita untuk mempercayai-Nya. Dia membuktikan Dia setia dan layak untuk mendapatkan kepercayaan kita." ${ }^{103}$

Dengan adanya realitas bahwa Allah membangkitkan Kristus dari kematian, maka iman Kristen dibangun di atasnya. Walaupun realitas kebangkitan dianggap suatu mitos atau khayalan bagi orang-orang yang menolak kekristenan, namun kenyataannya adalah iman Kristen tidak pernah didasarkan kepada apa yang dianggap sebagai mitos. Seperti yang dikatakan oleh R.C. Sproul,

Kekristenan tidak didasarkan pada mitos dan dongeng, tetapi atas dasar kesaksian dari mereka yang melihat dengan mata kepala sendiri dan mendengar dengan telinga mereka sendiri. Kebenaran dari Injil didasarkan pada peristiwa-peristiwa sejarah. Apabila kejadian dari peristiwa-peristiwa itu tidak dapat dipercayai, maka pada dasarnya iman kita itu sia-sia saja. Tetapi, Allah tidak meminta kita untuk mempercayai sesuatu berdasarkan suatu mitos. $^{104}$

Jika Kristus tidak dibangkitkan, maka pemberitaan dan iman orang-orang percaya adalah sia-sia, dan pemberita Injil adalah pendusta 61-62.

${ }^{102}$ J. L. Ch. Abineno, Aku Percaya Kepada Allah (Jakarta: BPK Gunung Mulia, 1983),

${ }^{103}$ R. C. Sproul, Kebenaran-Kebenaran Dasar Iman Kristen, Cetakan Keempat (Malang: Departemen Literatur Saat, 2002), 243.

${ }^{104}$ Sproul, Kebenaran-Kebenaran Dasar Iman Kristen, 244. 
(lihat I Korintus 15: 14,15,17). Namun, semuanya tidak akan pernah siasia sebab kebangkitan Kristus adalah suatu fakta. Iman Kristen benarbenar dapat dipertangungjawabkan. Bukan 'iman yang melompat di dalam gelap, melainkan iman Kristen memiliki landasan yang jelas dan benar karena Kristus benar-benar dibangkitkan oleh Allah. Percaya kepada Allah berarti mempercayai kuasa kebangkitan yang telah bekerja di dalam Kristus melalui peristiwa kebangkitan-Nya.

\section{Kebangkitan Kristus Dengan Karya Penebusan}

Tujuan utama Kristus datang ke dalam dunia adalah melaksanakan tugas dari Bapa-Nya. Misi yang dilaksanakannya adalah demi keselamatan seluruh umat manusia. Ia datang untuk menebus manusia dari belenggu kutuk dosa, maut, dan kuasa Iblis. Melalui kasih Allah yang dinyatakan-Nya kepada manusia di dalam karya penebusan, maka nyatalah karya penyelamatan. R.C. Sproul mengatakan, "Menebus berarti membebaskan seseorang dari kesalahan atau membuat sesuatu menjadi benar." ${ }^{105}$ Inilah yang dilakukan oleh Kristus bagi manusia yang sudah jatuh ke dalam dosa. Kristus membebaskan manusia dari berbagai ketakutan, kutuk karena belenggu kuasa dosa, dan kuasa-kuasa si jahat, serta maut. Selanjutnya dikatakan oleh R. C. Sproul bahwa, "Pada waktu menerima murka Allah di atas kayu salib, Kristus mampu untuk mengadakan penebusan untuk umat-Nya. Kristus menanggung penghukuman atas dosa-dosa umat manusia. Dia menebus mereka dengan cara menerima penghukuman yang seharusnya diterima oleh manusia atas dosa-dosa mereka."

Peristiwa penebusan tidak hanya sampai saat di mana Kristus mati di atas kayu salib. Peristiwa itu tidak mencapai kesempurnaanya dan dianggap gagal jika Kristus tidak dibangkitkan. Menurut J. Knox Chamblin, "Kebangkitan mengesahkan apa yang telah dicapai oleh salib." 107 Donald Guthrie juga mengatakan, "Kebangkitan merupakan bagian yang penting dari rencana Allah untuk penebusan umat Manusia." ${ }^{108}$ Orang percaya harus memahami bahwa ketika Kristus dibangkitkan, sebenarnya peristiwa tersebut menjadi penentu dari tindakan kasih Allah melalui karya penebusan. Di dalam suratnya kepada jemaat di Korintus Rasul Paulus mengatakan, "Dan jika Kristus tidak dibangkitkan, maka sia-sialah kepercayaan kamu dan kamu masih hidup dalam dosamu. Demikianlah binasa juga orang-orang yang mati

\footnotetext{
${ }^{105}$ R. C. Sproul, Kebenaran-Kebenaran Dasar Iman Kristen, 231.

${ }^{106} \mathrm{Ibid}$

${ }^{107}$ J. Knox Chamblin, Paulus dan Diri: Ajaran Rasuli Bagi Keutuhan Pribadi, Cetakan Kedua, (Surabaya: Momentum, 2008), 80.

${ }^{108}$ Donald Guthrie, Teologi Perjanjian Baru 1 (Jakarta: BPK Gunung Mulia, 1992), 446
} 
dalam Kristus. Jikalau kita hanya dalam hidup ini saja menaruh pengharapan pada Kristus, maka kita adalah orang-orang yang paling malang dari segala manusia." (I Korintus 15:17-19).

Jadi, penebusan yang dilakukan Kristus untuk membebaskan manusia dari belenggu kuasa dosa, maut, dan iblis melalui peristiwa penyaliban, kematian dan kebangkitan-Nya, menjamin adanya pengharapan untuk terus hidup dalam persekutuan dengan Kristus. Orang percaya harus menyadari bahwa Allah menyatakan tindakan kasih-Nya yang sempurna dan yang tidak terbatas untuk manusia melalui karya penebusan Kristus. Allah juga menyatakan kesempurnaan penebusan itu melalui kebangkitan Yesus Kristus.

\section{Kebangkitan Kristus Dengan Kebangkitan Orang Percaya}

Orang-orang yang hidup dalam persekutuan dengan Kristus memperoleh jaminan bahwa orang-orang percaya akan dibangkitakan pada saat kedatangan Kristus (parousia). Sebab Kristus telah menjadi yang sulung bangkit dari kematian. Peristiwa kebangkitan itu akan disusul oleh kebangkitan orang-orang yang menjadi milik kepunyaanNya. Rasul Paulus mengatakan, "Tetapi tiap-tiap orang menurut urutannya: Kristus sebagai buah sulung; sesudah itu mereka yang menjadi milik-Nya pada waktu kedatangan-Nya" (I Korintus 15:23). Kebangkitan Yesus adalah 'buah sulung' kebangkitan eskatologis pada akhir zaman." ${ }^{109}$ Kebangkitan Kristus dan kebangkitan mereka yang telah menjadi milik-Nya merupakan dua bagian dari satu peristiwa, dua babak dari satu drama, dua tahap dari satu proses. ${ }^{110}$

Adanya jaminan tentang kebangkitan, menimbulkan pengharapan itu terus membuat orang-orang kepunyaan-Nya akan terus hidup di dalam suatu keyakinan yang pasti walaupun hal itu belum tergenapi. Namun, akan tiba saatnya di mana orang-orang yang mati dalam Kristus akan dibangkitkan untuk bersama-sama dengan Dia di dalam kemuliaan-Nya. Jadi, melalui kebangkitan Kristus bukan hanya ada jaminan penebusan bagi umat manusia. Orang-orang yang hidup di dalam persekutuan dengan Kristus adalah orang-orang yang menjadi milik Kristus dan mereka akan dibangkitkan pada waktu kedatangan Kristus dengan segala kemuliaan-Nya menjemput semua orang-orang kudus.

\section{Kebangkitan Kristus Dengan Kemenangan}

Sejak Kristus dibangkitkan, pada saat itu jugalah kuasa maut tidak berkuasa lagi atas-Nya. Bahkan dikatakan bahwa segala pemerintahan, kuasa, dan kekuatan telah dibinasakan. Allah menyatakan kedaulatan-

\footnotetext{
${ }^{109}$ Eldon George Ladd, Teologi Perjanjian Baru 2 (Bandung:Kalam Hidup, 1999),32.

${ }^{110}$ Ibid., 32.
} 
Nya melalui kebangkitan Kristus. Ia berkuasa lebih daripada segala sesuatu. Baik atas alam, manusia, maupun kuasa-kuasa kegelapan dan bahkan kematian. Ketika Kristus mengalami kematian bukan berarti bahwa maut mengalami kemenangan, tetapi melalui kematian-Nya Ia akan menyatakan kemakuasaan-Nya bahwa maut tidak bisa berkuasa atas diri-Nya. Sekalipun di dunia ini, dosa kematian, dan iblis masih ada, namun orang percaya harus yakin bahwa kuasa iblis, maut, dan kutukan dosa telah dipatahkan melalui peristiwa penebusan dan kemenangan yang sempurna atas maut melalui kebangkitan-Nya. Dan itu akan mencapai puncaknya serta tergenapi pada akhir zaman. Sebab Allah yang meletakkan dan menaklukkan semua musuh-Nya di bawah kakiKristus (I Korintus 25 dan 27). Di mana Kristus telah menaklukkan segala pemerintahan, kuasa, dan kekuatan dari si jahat tersebut (I Korintus 15:24). Akan tiba saatnya semuanya akan mengalami penghancuran total sebelum Kristus menyerahkan kerajaan kepada Allah Bapa, yaitu pada akhir zaman. Dan musuh terakhir yang dibinasakan adalah maut (I Korintus 15:26). Jadi, kemenangan Kristus juga memberikan jaminan kemenangan kepada umat-Nya. Dengan kemenangan Kristus, karya penebusan di kayu salib yang disempurnakan melalui kebangkitan-Nya mengalahkan kuasa dosa sehingga adanya pengampunan dosa. Kuasa maut tidak dapat berkuasa atas mereka, tetapi melalui kematian jasmani yang dialami menjadi jalan untuk dibangkitkan dengan tubuh yang rohani, rupa sorgawi (I Korintus 15:40,49) pada saat kedatangan Kristus (parousia). Begitupun dengan kuasa iblis dan pemerintahannya yang telah digulingkan oleh Allah. Dan semuanya itu, akan mencapai puncaknya pada akhir zaman.

\section{PENUTUP}

\section{Kesimpulan}

Dari seluruh hasil uraian penulis melalui karya ilmiah tentang makna kebangkitan Kristus bagi orang percaya berdasarkan I Korintus 15:12-28, maka penulis menyimpulkannya sebagai berikut:

Pertama, Kristus adalah Allah yang menjadi manusia sejati. Sebagai manusia Kristus mengalami kematian tubuh. Tetapi di dalam Dia, Allah hadir dan bertindak membangkitkan-Nya dari kematian itu.

Kedua, kebangkitan Kristus adalah bagian dari Injil yang utuh yang diberitakan sekaligus meneguhkan pemberitaan Injil. Sebab, pemberitaan Injil yang lengkap tidak terpisahkan dari peristiwa dan pemberitaan kebangkitan Kristus.

Ketiga, kebangkitan Kristus menjadi penentu dari seluruh ajaran Kristen sehingga tegak atau runtuhnya iman Kristen didasarkan kepada realitas kebangkitan Kristus. 
Keempat, kebangkitan Kristus adalah salah satu penentu tentang jaminan karya penebusan Allah yang sempurna melalui Anak-Nya yaitu YesusKristus.

Kelima, kebangkitan Kristus adalah dasar kebangkitan orang-orang percaya pada saat kedatangan Kristus yang kedua kalinya (parousia). Oleh sebab itu, orang-orang percaya tidak usah takut menghadapi kematian. Orang-orang percaya harus mempunyai pengharapan bahwa setelah mati akan ada waktunya dibangkitkan kembali dengan tubuh yang rohani di dalam kehidupan yang kekal. 


\section{KEPUSTAKAAN}

Alkitab

Alkitab Edisi Studi. Jakarta: Percetakan Lembaga Alkitab Indonesia, 2010.

Alkitab Penuntun Hidup Berkelimpahan. Malang: Gandum Mas, 2010.

Alkitab Elektronik 2.0.0- Terjemahan Baru. Jakarta:Lembaga Alkitab Indonesia, 1974.

BibleWorks 2006, Version 7.0.012

Kamus

Echols, Jhon M. Dan Hasan Shadily. Kamus Inggris Indonesia. Jakarta: Gramedia Jakarta, 1989.

Ensiklopedi Alkitab Masa Kini Jilid I (A-L). Jakarta:Yayasan Bina Kasih/OMF, 1997.

Salim, Peter. Advanced English-Indonesia Dictionary. Jakarta: Modern English Press, 1989.

Strong, James. The New Strong's Exhaustive Concordance of the Bible. Nashhville, Atlanta, London, Vancouver: Thomas Nelson Publishers, 1996.

\section{Buku-Buku}

Abineno, J. L. Ch. Aku Percaya Kepada Allah. Jakarta: BPK Gunung Mulia, 1983.

Barclay,William. Pemahaman Alkitab Setiap Hari:Surat I dan II Korintus. Jakarta: BPK Gunung Mulia, 2009.

Brill, J. Wesley. Tafsiran Surat Pertama Korintus. Bandung:KalamHidup, 1994.

Chamblin, J. Knox. Paulus dan Diri: Ajaran Rasuli Bagi Keutuhan Pribadi. Surabaya: Momentum, 2008.

Drewes, B. F. Wilfrid Haubeck, dan Heinrich von Siebenthal, Kunci Bahasa Yunani Perjanjian Baru Surat Roma Hingga Kitab Wahyu. Jakarta: BPK GunungMulia, 2010.

Fernando, Ajith. Supremasi Kristus. Surabaya:Penerbit Momentum, 2006.

Guthrie, Donald. Teologi Perjanjian Baru 1. Jakarta:BPK Gunung Mulia, 1992.

Ibrahim, David. Pelajaran Surat I Korintus. Jakarta: Mimery Press, 1999.

Ladd, Eldon George. Teologi Perjanjian Baru 2. Bandung: Kalam Hidup, 1999. 
Mounce, William D. Basic of Biblical Greek; Dasar-dasar Yunani Biblika. Malang: Literatur SAAT, 2011.

Newman Jr, Barclay M. KamusYunani-Indonesia. Jakarta: BPK Gunung Mulia, 1991.

Pate, C. Marvin dan Sherly L. Pate, Disalibkan oleh Media. Yogyakarta: Penerbit ANDI, 2007.

Pfitzner, Victor C. Ulasan Atas 1 Korintus; KesatuanDalam Kepelbagaian. Jakarta : BPK Gunung Mulia, 2010.

Pfeiffer, Charles F. dan Everett F. Harrison. Tafsiran AlkitabWiycliffe Volume 3 Perjanjian Baru. Malang: Gandum Mas, 2001.

Ridderbos, Herman. Paulus: Pemikiran Utama Theologinya. Surabaya: Momentum, 2008.

Sproul, R. C. Kebenaran-Kebenaran Dasar Iman Kristen. Malang: Departemen Literatur SAAT, 2002.

Subekti,Timotius. Kesucian. Yogyakarta: ANDI OFFSET, Cetakan Pertama. 1986.

Sutanto, Hasan. Perjanjian Baru Interlinear Yunani-Indonesia dan Konkordansi Perjanjian Baru, Jilid I dan II. Jakarta: LembagaAlkitab Indonesia, 2010.

Tenney, Merrill C. Survey PerjanjiamBaru. Malang: Gandum Mas, 2003.

Wenham, J.W. Bahasa Yunani Koine. Diterjemahkan dan disadur oleh Lynne Newell. Malang: SeminariAlkitab Asia Tenggara, 1977.

Wiersbe, Warren W. Hikmat Di Dalam Kristus. Bandung: KalamHidup, 1983.

Wilson, A. N. Jesus: A life. New York: Ballatine, 1992.

\section{Internet}

Utley, Bob. "Surat-surat Paulus kepada Sebuah Gereja yang Bermasalah: I dan II

Korintus (Kumpulan Komentari Panduan Belajar, Perjanjian Baru, Vol. 8

Bible Lesson International, Marshall, Texas 1997 Revisi 2011) diakses tanggal 11 Mei 2012, tersedia di

http://www.freebiblecommentary.org/pdf/ind/VOLO6_indonesian.pdf

"Buntut Tulisan Kontroversi Temuan Makam Keluarga Yesus"; diakses tanggal 07 Juni 2012; tersedia di http://www.jawaban.com/index.php/mobile/news/detail_text_view/id/90/news/ 071018095337/page/1670/limit/15

Jerusalem (I Korintus 15:14), diakses tanggal 26-04-2012 tersedia di http://alkitab.sabda.org/commentary.php?passage=1Kor\%2015:1234 